UDC $342.7+351.74$

DOI: $10.31733 / 2078-3566-2019-5-36-41$

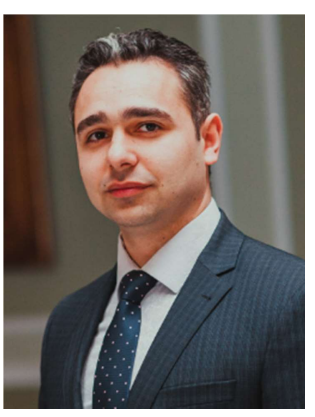

Karen ISMAYLOV ${ }^{\odot}$

Ph.D

(Odesa State University of Internal Affairs)

\title{
PECULIARITIES OF HUMAN RIGHTS AND FREEDOM WHILE APPLYING INTELLIGENCE-LED POLICING (ILP)
}

КареН ІсмайЛов. ОСОБЛИВОСТІ ЗАБЕЗПЕЧЕННЯ ПРАВ І СВОБОД ЛЮДИНИ ПРИ МОДЕЛІ ПОЛІЦЙСЬКОЇ ДІЯЛЬНОСТІ, КЕРОВАНОЇ АНАЛІТИЧНОЮ РОЗВІДКОЮ (ILP). Розглядаються основні національні та міжнародні норми та принципи, якими керуються співробітники поліції при здійсненні поліцейської діяльності, керованої аналітичною розвідкою для забезпечення стандартів прав і свобод людини і громадянина. За результатами аналізу Стратегії розвитку системи Міністерства внутрішніх справ України до 2020 року визначено, що на сьогодні рівень використання інформаційно-аналітичних інструментів поліцейськими знаходиться на низькому рівні та потребує вдосконалення шляхом реалізації концепції діяльності органів системи МВC, заснованої на використанні різних джерел інформації (Intelligence Led Policing), а також комплексного впровадження сучасних систем кримінального аналізу. Стверджується, що натепер правоохоронна діяльність змінюється як в оперативній тактиці, та і організаційних структурах, шляхом упровадження нової філософії боротьби зі злочинністю та правоохоронної практики, якою $є$ правоохоронна діяльність, керована аналітичною розвідкою, яка $є$ моделлю, яка передбачає інкорпорування розвідувальної аналітичної функції в загальну місію правоохоронної системи. Зазначено, що кримінальний аналіз будучи специфічним видом інформаційно-аналітичної діяльності поліції формує нову сферу взаємодії співробітників поліції з суспільством на основі аналітичної розвідки, яка має ряд особливостей, в тому числі в питаннях дотримання основоположних прав і свобод людини і громадянина. Зроблено висновок, що порушення прав та свобод людина при моделі поліцейської діяльності, керованої аналітичною розвідкою $є$ контпродуктивним та неефективним в довгостроковій перспективі, оскільки це підриває довіру громадян до поліції, тому важливо, щоб різні оперативні методи збору інформації, які втручаються в права людей повинні мати ефективний контроль з боку судових або інших незалежних органів, до яких звертаються за попереднім дозволом поліцейські для проведення цих заходів. розвідка.

Ключові слова: права та свободи людини і громадянина, кримінальний аналіз, аналітична

Problem statement. In Ukraine, the protection of human and citizen rights and freedoms is one of the main tasks of the process of reforming Ukrainian society, which is of particular importance in the context of European integration in general and the reform of the National Police of Ukraine in particular.

The Strategy for the Development of the Ministry of Internal Affairs of Ukraine until 2020, within the framework of crime counteraction, draws attention to the low level of use of analytical tools of police in the fight against crime and the forecasting of relevant threats. based on the use of different sources of information (intelligence led-policing), comprehensive implementation of modern criminal analysis systems, including the Europol methodology [1].

Today we are already observing the creation of new analytical units of the National Police of Ukraine (Criminal Analysis Department of NPU) and the gradual transition of other police units to the use of modern information-analytical software and investigative methods (SOCTA), which certainly improves the effectiveness of the activities of police bodies and units during the execution tasks for the protection of human rights and freedoms and combating crime. Thus, implementing a model of proactive activity that replaces the dominant paradigm of reactive policing. Thus, with the introduction of new modern information technologies and highly intelligent software into police activity, a new field is emerging, where the issue of ensuring human rights and freedoms in the model of intelligence-led policing (ILP) is not yet

(C) Ismaylov K., 2019

ORCID iD: https://orcid.org/0000-0001-5137-2507

oduvs@cybercrime.gov.ua 
discussed enough at the scientific level and at the legislative level, that is why this issue becomes relevant today.

Analysis of publications that started solving this problem. Some aspects of the use of the model of police activity, guided by analytical intelligence in the activity of law enforcement agencies, were considered in their scientific works Albul S.V., Varenko V.M., Yesimov S.S., Zaiets O.M., Ismailov K.Iu., Kytsiuk V.P., Korystin O.Ie., Movchan A.V., Nekrasov V.A., Ryzhkov E.V. and other scientists.

According to Udo Moller, Head of the Operations Department of the European Union Advisory Mission: «Some units of the National Police of Ukraine operate in accordance with some principles of intelligence-led policing, but at present this phenomenon is not yet part of the institutional culture of the Ukrainian police [2].

Professor Movchan A.V. in his writings analyzes the current problems of implementation in the bodies of the National Police of Ukraine model of intelligence-led policing [3, p. 17-22].

In the monograph «Organizational and legal support of analytical work in the system of the Ministry of Internal Affairs of Ukraine (law enforcement and security aspects)» Professor Korystin O.Ie. examines the fundamental rights, principles and content of basic elements in the system of analytical intelligence [4, p. 254-266].

Yes, there is still some imperfection in the methods and tactics of law enforcement, which is the result of the use of an outdated crime investigation system and not implementing of intelligence-led policing [5]. Today, however, the issue of human rights observance of police intelligence is hardly raised, and it is essential to ensure the effective short-term and long-term enforcement of law enforcement agencies, including intelligence-led policing. Law enforcement measures that do not respect and protect human rights are counterproductive and ineffective in the long run, as they undermine public confidence in the police as a whole.

The article's objective: based on the precautionary principle, the intelligence-led policing must be firmly based on human rights standards and promote the protection of human rights and freedoms, and be carried out in such a way as to ensure full respect for human rights, which is in line with the key principles of democratic policing.

Basic content. As for the national legislation of Ukraine governing public relations in the sphere of protection of human rights and freedoms, it is first of all the Constitution of Ukraine, laws and regulations, international treaties of Ukraine, the consent of which is provided by the Verkhovna Rada of Ukraine. Regarding specialized legal acts, it is necessary to highlight the Law of Ukraine «On National Police», which in Art. 2 stated that one of the main tasks of the police was to provide police services in the field of protection of human rights and freedoms, as well as the interests of society and the state. Section II «Principles of police activity» of the said law lists the basic principles that govern the police in its activities, namely:

- Rule of Law. Man, his rights and freedoms are recognized as the highest values and determine the content and orientation of the state.

- respect for human rights and freedoms. The police ensure the observance of human rights and freedoms, which are regulated by the legislation of Ukraine, and restricts human rights and freedoms when urgently needed and to the extent necessary for police tasks.

- legality. The police shall act solely on the basis, within the limits of their authority and in the manner specified by the legislation of Ukraine.

- Openness and transparency. The police ensure that public authorities and the public are kept informed of their activities in the field of protection and protection of human rights and freedoms, combating crime, ensuring public safety and order.

- Political neutrality. The police protect human rights and freedoms regardless of political beliefs and party affiliation.

- Interaction with the community on the basis of partnership. The activities of the police are carried out in close cooperation and interaction with the public on the basis of partnerships and aimed at meeting their needs.

- Continuity. The police ensure the continuous and round-the-clock fulfillment of their tasks [6, Art. 2, Art. 6-12].

We agree with the opinion of Kolodii A.M. and Oliinyk A.Iu., that police activity has an external and internal side. External aspect - ensuring the realization of a person's rights is characterized by the fact that the police: a) perform their tasks impartially, in exact accordance with the law; b) respects the dignity of the person and shows a humane attitude towards him; 
c) protect human and citizen's rights regardless of origin, property and other status, race and nationality, citizenship, age, language and education, attitude to religion, gender, political and other beliefs; d) do not disclose information concerning a person's personal life, degrades his / her honor and dignity, unless his / her duties require otherwise; e) temporarily, within the limits of the current legislation, restrict the rights and freedoms of a person, if it is not possible to perform the duties assigned to him / her without this; e) ensure the right to protection and other legal rights of arrested and detained; g) create conditions for the exercise of rights, protects and defends the person from the offense, take all measures envisaged by law to restore the violated right. The internal side of the activity is characterized by the fact that the police: a) within the limits of their tasks and functions, their competence performs their duties; b) apply lawful measures of physical influence, special means and firearms; c) use legal and organizational forms and methods while ensuring human and citizen's rights; d) its employees should not violate the laws, rights and freedoms of the person [7, p. 293].

For police officers who carry out analytical work, it is extremely important to comply with the Law of Ukraine «On Personal Data Protection», which regulates legal relations related to the protection and processing of personal data, and is aimed at protecting fundamental rights and freedoms of individuals and citizens, in particular the right to privacy interference with the processing of personal data and extends to the processing of personal data, which is carried out wholly or in part by the use of automated means, as well as to the processing of personal data personal data contained in the file or intended to be included in the file, using non-automated means.

In Art. 7 of the mentioned law there are specific requirements for the processing of personal data, which are required by paragraph 1, which prohibits the processing of personal data on racial or ethnic origin, political, religious or ideological beliefs, membership in political parties and trade unions, sentencing to criminal penalties, as well as health, sexual, biometric or genetic data. However, personal data may be processed in accordance with paragraph 2 of the mentioned article, concerning the court's judgments, execution of tasks of operativeinvestigative or counter-intelligence activity, counter-terrorism and carried out by a state body within the limits of its powers defined by law [12].

Basic human rights norms are set out in international legal documents and standards such as the International Covenant on Civil and Political Rights [8] and the Council of Europe Convention on the Protection of Human Rights and Fundamental Freedoms [9]. Within which, one of the main responsibilities of the police is to protect citizens from actions that threaten their rights as a human being and the enforcement of these rights by law enforcement agencies.

In Ukraine, the implementation of a model of intelligence-led policing is actively addressed by international institutions as:

- European Union Advisory Mission (EUAM), which sent a letter No. 2017-EUAM-0062 to the Ministry of Internal Affairs of Ukraine on January 20, 2017, which contained: 1. Report on needs for the implementation of intelligence-led policing; 2. Schedule of support for implementation of the model of intelligence-led policing; 3. The EUAM vision of the requirements and expectations for candidates for training and study trips. In addition, international scientific events are conducted under the aegis of the EUAM, and a number of educational, practical, methodological and scientific materials have been released, which are devoted to the implementation of criminal analysis in the law enforcement activities of Ukraine.

- the Strategic Affairs Unit of the Organization for Security and Cooperation in Europe (OSCE) Transnational Threats Transnational Threats Unit, which in June 2017 issued an OSCE Handbook on Police Based on Operational Data and Information, as well as other regional training materials trainings on the subject.

In their teaching materials and during trainings, the EUAM and the OSCE constantly focus on respect for human rights and freedoms in intelligence-led policing, and cite specific international best practices. For example, at the OSCE event on December 12-13, 2019 in Kyiv, «Implementing proactive, operational-based and information-based approaches to the prosecution of transnational organized crime groups» gave an example of ethnic profiling (police activity against persons based on them) on stereotypical, broad, and unqualified assumptions regarding nationality, ethnicity, or religion) is discriminatory, and has proven to be an ineffective measure since it can be easily circumvented and, that criminal groups may avoid detection, picking up people who do not meet the predefined «profiles» signs. Alternative legal profiling methods based on specific evidence of criminal behavior rather than discriminatory assumptions can be used as a more effective tool in policing [10, p. 24].

According to Art. 17 of the International Covenant on Civil and Political Rights, no 
person shall be subjected to arbitrary or unlawful interference with his or her personal and family life, arbitrary or unlawful encroachments on the integrity of his home or the secrecy of his correspondence or unlawful encroachments on his honor and reputation, and everyone has the right to protect the law against such interference or encroachment [8].

In order to ensure that intelligence-led policing are in line with international human rights standards and to avoid adversely affecting human rights, a number of fundamental principles must be observed when designing and implementing such activities at the national level [11, p. 57-59]:

- The legal, administrative and institutional framework for the implementation of intelligence-led policing. ILP must be based on clear and precise legal provisions that will set out the conditions in which they are to be implemented and ensure that they do not jeopardize human rights. In addition, police officers involved in intelligence-led policing should be properly trained in applying these laws, methods and rules in accordance with national and international human rights standards.

- Legality, necessity and proportionality of limitations of human rights. Such as the prohibition of torture and certain elements of the right to a fair trial, are absolute and cannot be restricted in all circumstances, international human rights treaties allow restrictions to be placed on certain rights, but only within clearly defined parameters (such as freedom of movement, right to privacy, freedom of expression, assembly, freedom to profess one's religion). Accordingly, interventions related to the conduct of police activities aimed at obtaining intelligence are only permissible when they are required by law and necessary in a democratic society for the legitimate purpose specifically mentioned in relevant international human rights standards and proportionate to this goal: that is, the law is the rule, restraint should remain the exception, and interference should always be the least intrusive means of achieving the goal.

- Equality, non-discrimination and tolerance. Ensuring everyone's human rights without discrimination on any grounds, such as race, color, gender, language, religion, political or other beliefs, national or social origin, property status, birth or other status. The protection of equality before the law and the prohibition of discrimination are the main responsibilities of the police in a democratic society. Therefore, when collecting, processing and analyzing information and intelligence, law enforcement agencies should, for example, refrain from discriminating. Similarly, when it comes to decision-making on the basis of operational data and information, police officers should exercise due care to avoid unduly harsh action on specific communities that could lead to discrimination. Particular attention should also be paid to the different impact of strategic decisions in the field of analytics-driven policing on women and men. Therefore, diversity and gender should be mainstreamed into police activities aimed at obtaining intelligence, which should be regularly reviewed for any discriminatory influence they may have on women and men or on specific communities.

- Effective remedies, oversight and accountability. International human rights standards provide for the right of every person whose rights or freedoms are violated to effective remedies by a competent judicial, administrative or legislative body. Because intelligence-led police activities can lead to potentially excessive human rights interventions, effective and affordable remedies for human rights violations that may result from these activities are important. In addition, to ensure that proper internal and external oversight mechanisms are in place to ensure the accountability of agencies and individual law enforcement agencies involved in intelligence-led policing. Such mechanisms may include control and oversight of executive bodies, legislative oversight committees, and independent external oversight and complaint mechanisms that enable individuals to obtain protection to ensure appropriate safeguards against abuse in the use of intelligence-led policing [10, p. 25].

Conclusions. Thus, the National Police of Ukraine has today adopted a modern management model for decisions on reasonable allocation of resources, taking into account the directions and spheres of activity of serial crimes and organized criminal groups, which involves the incorporation of intelligence analytical function in the overall Ukrainian law enforcement system. In this process, a new sphere of interaction between police officers and the public is formed on the basis of intelligence-led policing, which has a number of features, including in matters of respect for fundamental rights and freedoms of man and citizen, as the collection of data and information, as well as their processing, analysis and joint use, are integral elements of intelligence-led policing. Clear observance of human rights and freedoms is essential to ensure the short and long term effectiveness of the National Police. Law 
enforcement activities that are abused and / or neglected are human rights that are counterproductive and ineffective in the long run, as they significantly undermine public confidence in the police. Therefore it is important that the various operational methods of gathering information, which represent different degrees of interference with human rights, have effective control by the judicial or other independent bodies, which are requested by police to seek appropriate action.

\section{References:}

1. Про схвалення Стратегії розвитку органів системи Міністерства внутрішніх справ на період до 2020 року: розпорядження КМУ від 15.11.2017 № 1023-p. URL: https://zakon3.rada.gov.ua/laws/show/1023-2017-\%D1\%80/.

2. Правоохоронна діяльність, керована аналітикою: передова методика сучасної правоохоронної діяльності. URL: http://www.euam-ukraine.eu/ua/news/opinion/intelligence-led-policing-thecutting-edge-of-modern-law-enforcement/.

3. Мовчан А.В. Актуальні проблеми впровадження в органах Національної поліції України моделі поліцейської діяльності, керованої аналітикою. Соціально-правові студї. 2018. Випуск 1. C. 17-22. URL: http://www.lvduvs.edu.ua/documents_pdf/biblioteka/sps/SPS_2018_1/05.pdf.

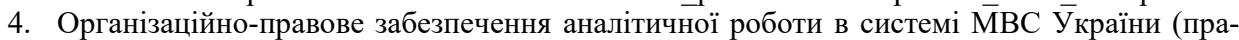
воохоронний та безпековий аспекти) : монографія / О.С. Користін, І.В. Парубочий, Л.М. Доля та ін. ; за заг. ред. д-ра юрид. наук, проф. М.Г. Вербенського. Херсон : Видавничий дім «Гельветика», 2019. $328 \mathrm{c}$.

5. Ісмайлов К.Ю. Особливості кримінальної розвідки з відкритих джерел як інструмент збирання оперативної інформації. Південноукраїнський правничий часопис. ОДУВС, 2016. № 2. C. $110-113$.

6. Про Національну поліцію: Закон України від 02.07.2015 № 580-VIII. Відомості Верховної Ради України. 2015. № 40-41. Ст. 379.

7. Колодій А. М., Олійник А. Ю. Права людини і громадянина в Україні : навч. посібник. Київ : Юрінком Інтер, 2003. 336 с.

8. Міжнародний пакт про громадянські і політичні права: Міжнародний пакт ратифіковано Указом Президії Верховної Ради Української РСР № 2148-VIII ( 2148-08 ) від 19.10.1973 р. URL: http://zakon3.rada.gov.ua/laws/show/995_043.

9. Конвенція про захист прав людини і основоположних свобод. Рада Свропи: Конвенція, Міжнародний документ від 04.11.1950 р. Офіційний вісник Украӥни. 16.04 .1998 р. № 13 / 23.08.2006. № 32. С. 270. URL: https://zakon.rada.gov.ua/laws/show/995_004/ed19900101.

10. Руководство ОБСЕ по полицейской деятельности на основе оперативных данных и информации. ДТНУ/ОСВПД, издание 13, Вена, 2017. 108 с.

11. Довідник керівника поліції - поліцейська діяльність, керована розвідувальною аналітикою / ILP : навчальний посібник / Користін О.С., Пефтієв Д.О., Пеньков С.В., Некрасов В.А.; за заг. ред. Вербенського М.Г. Київ : «Видавництво Людмила», 2019. 120 с.

12. Про захист персональних даних: Закон України від 01.06.2010 № 2297-VI. Вiдомості Верховної Ради України. 2010. № 34. Ст. 481.

Received to editorial office 04.12.2019

1. Pro skhvalennya Stratehiyi rozvytku orhaniv systemy Ministerstva vnutrishnikh sprav na period do 2020 roku [On approval of the Strategy of development of bodies of the system of the Ministry of Internal Affairs for the period up to 2020]: rozporyadzhennya KMU vid 15.11.2017 № 1023-r. URL: https://zakon3.rada.gov.ua/laws/show/1023-2017-\%D1\%80/. [in Ukr.]

2. Pravookhoronna diyal'nist', kerovana analitykoyu: peredova metodyka suchasnoyi pravookhoronnoyi diyal'nosti [Analytics-led law enforcement: an advanced method of modern law enforcement activities]. URL: http://www.euam-ukraine.eu/ua/news/opinion/intelligence-led-policing-the-cutting-edgeof-modern-law-enforcement/. [in Ukr.]

3. Movchan, A. V. (2018) Aktual'ni problemy vprovadzhennya v orhanakh Natsional'noyi politsiyi Ukrayiny modeli politseys'koyi diyal'nosti, kerovanoyi analitykoyu [Analytics-led law enforcement: an advanced method of modern law enforcement activities]. Sotsial'no-pravovi studiyi. Vypusk 1. S. 17-22. URL: http://www.lvduvs.edu.ua/documents_pdf/biblioteka/sps/SPS_2018_1/05.pdf. [in Ukr.]

4. Orhanizatsiyno-pravove zabezpechennya analitychnoyi roboty v systemi MVS Ukrayiny (pravookhoronnyy ta bezpekovyy aspekty) [Analytics-led law enforcement: an advanced method of modern law enforcement activities]: monohrafiya / O. Ye. Korystin, I. V. Parubochyy, L. M. Dolya ta in. ; za zah. red. d-ra yuryd. nauk, prof. M. H. Verbens'koho. Kherson : Vydavnychyy dim «Hel'vetyka», 2019. 328 s. [in Ukr.]

5. Ismaylov, K. Yu. (2016) Osoblyvosti kryminal'noyi rozvidky z vidkrytykh dzherel yak instrument zbyrannya operatyvnoyi informatsiyi [Features of open source criminal intelligence as a tool for gathering operational information]. Pivdennoukrayins'kyy pravnychyy chasopys. ODUVS. № 2. S. 110-113. [in Ukr.]

6. Pro Natsional'nu politsiyu [On the National Police]: Zakon Ukrayiny vid 02.07.2015 № 580-VIII. Vidomosti Verkhovnoyi Rady Ukrayiny. 2015. № 40-41. St. 379. [in Ukr.]

7. Kolodiy, A. M., Oliynyk, A. Yu. (2003) Prava lyudyny i hromadyanyna v Ukrayini [Human and citizen rights in Ukraine]: navch. posibnyk. Kyyiv : Yurinkom Inter,. 336 s. [in Ukr.]

8. Mizhnarodnyy pakt pro hromadyans'ki i politychni prava [International Covenant on Civil and Political Rights]: Mizhnarodnyy pakt ratyfikovano Ukazom Prezydiyi Verkhovnoyi Rady Ukrayins'koyi RSR № 
2148-VIII ( 2148-08 ) vid 19.10.1973 r. URL: http://zakon3.rada.gov.ua/laws/show/995_043. [in Ukr.]

9. Konventsiya pro zakhyst prav lyudyny i osnovopolozhnykh svobod [Convention for the Protection of Human Rights and Fundamental Freedoms]. Rada Yevropy: Konventsiya, Mizhnarodnyy dokument vid 04.11.1950 r. Ofitsiynyy visnyk Ukrayiny. 16.04 .1998 r. № 13 / 23.08.2006. № 32. S. 270. URL: https://zakon.rada.gov.ua/laws/show/995 004/ed19900101. [in Ukr.]

10. Rukovodstvo OBSE po polytseyskoy deyatel'nosty na osnove operatyvnykh dannykh y ynformatsyy [OSCE Police Guide on the basis of operational data and information]. DTNU/OSVPD, yzdanye 13, Vena, 2017. 108 s. [in Russ.]

11. Dovidnyk kerivnyka politsiyi - politseys'ka diyal'nist', kerovana rozviduval'noyu anali-tykoyu [Directory of the police chief - police activity guided by intelligence analytics] / ILP : navchal'nyy posibnyk / Korystin O.YE., Peftiyev D.O., Pen'kov S.V., Nekrasov V.A.; za zah. red. Verbens'koho M.H. Kyyiv : «Vydavnytstvo Lyudmyla», 2019. 120 s. [in Ukr.]

12. Pro zakhyst personal'nykh danykh [On protection of personal data]: Zakon Ukrayiny vid 01.06.2010 № 2297-VI. Vidomosti Verkhovnoyi Rady Ukrayiny. 2010. № 34. St. 481. [in Ukr.]

\section{Summary}

In the article the basic national and international norms and principles are examined, which are used by police officers in conducting intelligence-led policing to ensure the standards of human and citizen rights and freedoms. It is noted that criminal analysis, being a specific type of information and analytical activity of the police, forms a new sphere of interaction of police officers with the society on the basis of analytical intelligence, which has a number of features, including in matters of respect for fundamental rights and freedoms of man and citizen. It is concluded that the violation of human rights and freedoms in the model of police intelligence-led intelligence is counterproductive and ineffective in the long run, since it undermines citizens' trust in the police, so it is important that different operational methods of collecting information that interfere with human rights should have effective scrutiny by the judicial or other independent bodies to which police officers seek prior permission to carry out these activities.

Keywords: human and citizen's rights and freedoms, criminal analysis, analytical intelligence.

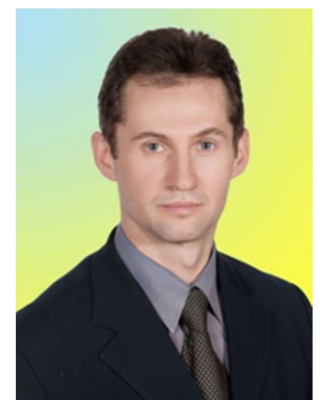

\author{
Dmytro \\ KAZNACHEYEV ${ }^{\odot}$ \\ Ph.D, Ass. Prof.
}
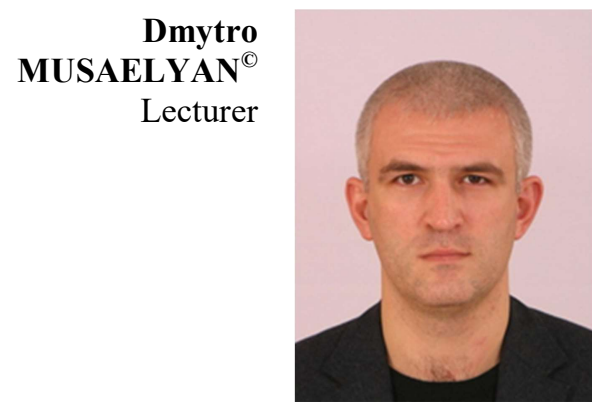

(Dnipropetrovsk State University of Internal Affairs)

\section{LEGAL REQUIREMENTS FOR THE PURCHASE, STORAGE AND WEARING OF WEAPONS IN UKRAINE}

Дмитро Казначесв, Дмитро Мусаелян. ПРАВОВІ ВИМОГИ ЩОДО ПРИДБАННЯ, ЗБЕРІГАННЯ ТА НОСІННЯ ЗБРОЇ В УКРАЇНІ. Здійснено аналіз відомчих нормативноправових актів, що регламентують порядок придбання, зберігання та продажу вогнепальної зброї громадянам України, які ліцензійні вимоги існують в Україні щодо покупки, зберігання та продажу вогнепальної зброї фізичним особам і організаціям, відповідність їх сучасним реаліям. Проводиться ретроспективний аналіз щодо навчання вогневої підготовки кандидатів на придбання вогнепальної зброї за часів Радянського Союзу та в сучасній Україні. Розглядаються правові вимоги, в тому числі вікові терміни і параметри навчання, володіння та користування зброєю, ситуації, права, умови та підстави за яких громадяни України можуть придбати у власне користування нарізну вогнепальну зброю. Особлива увага приділена проведенню спеціального навчання навичкам

(C) Kaznacheyev D., 2019

ORCID iD: https://orcid.org/0000-0001-5193-7176

k_tsp@dduvs.in.ua

(C) Musaelyan D., 2019

k_tsp@dduvs.in.ua 